\author{
Mateusz M. Krawczyk \\ Uniwersytet Wrocławski \\ mateusz.krawczyk@uwr.edu.pl
}

\title{
SPRAWCZOŚĆ UCHODŹCÓW W CZASIE PANDEMII COVID-19. PRZYPADEK OBOZU W NAKIVALE (UGANDA)
}

\section{The agency of refugees during the COVID-19 pandemic. The case of the Nakivale settlement (Uganda)}

Streszczenie. Życie uchodźców obarczone jest wieloma wyzwaniami, a pandemia COVID-19 dodatkowo je spotęgowała. Odwołując się do teorii strukturacji Anthony’ego Giddensa, niniejszy artykuł stanowi próbę analizy zagrożeń, przed jakimi stanęli uchodźcy podczas kryzysu zdrowia publicznego. Próbując odpowiedzieć na pytanie, jak manifestowała się sprawczość uchodźców podczas pandemii COVID-19, szczególny nacisk położono na kategorię relacji podmiotu i struktury na przykładzie zachowań w obozie w Nakivale (Uganda), którego mieszkańcy żyją w przedłużającym się stanie „zawieszenia” (ang. protracted refugee situations). W artykule wykorzystano narracje, informacje i dane udostępnione przez przedstawicieli Nakivale Researchers Network sieci badawczej zlokalizowanej w obozie w Nakivale. Metodologia tej pracy oparta została na koncepcie współobecności (ang. co-presence), wykorzystaniu tzw. „technologii życia”, pogłębionych wynikami wywiadu terenowego zrealizowanego w Nakivale przed pandemią COVID-19.

Slowa kluczowe: sprawczość, struktura, podmiotowość, upodmiotowienie, integracja, liminalność, stan zawieszenia. 


\begin{abstract}
The lives of refugees are burdened with challenges, which have been aggravated by the COVID-19 pandemic. Referring to Anthony Giddens' structuring theory, this article attempts to analyse the threats faced by refugees during the public health crisis. In an attempt to find an answer to the question of how the agency of refugees manifested itself during the COVID-19 pandemic, special emphasis has been placed on the relationship between the subject and structure on the example of the Nakivale (Uganda) settlement, whose inhabitants live in a prolonged state of "protraction". The article uses narratives, information and data provided by representatives of the Nakivale Researchers Network; a research network located in the Nakivale camp. The methodology of this work is based on the concept of co-presence, the use of the so-called "Technology of life", combined with the results of the field interview carried out in Nakivale before the outbreak of the COVID-19 pandemic.
\end{abstract}

Keywords: agency, structure, subjectivity, empowerment, integration, liminality, "protratcted refugee situations"

\title{
Wprowadzenie
}

Obóz dla uchodźców w Nakivale w południowej Ugandzie jest zamieszkany przez ponad 100 tysięcy osób z wielu państw afrykańskich. Od wielu lat kraj ten prowadzi politykę „otwartych drzwi” wobec potencjalnych azylantów. Jednak, jak wskazuje Frank Ahimbisibwe (2019), chociaż jest chwalony za liberalną politykę wobec uchodźców, to na tamtejszą gościnność wpływa szereg wyzwań, miedzy innymi: rosnąca liczba osób żyjących w ,stanie zawieszenia” (ang. protracted refugee situations), obciążenia systemowe i niewielkie wsparcie międzynarodowe. Pandemia COVID-19 przyczyniła się z kolei do wystąpienia nowych trudności związanych ze źródłami utrzymania i sprawczością uchodźców na całym świecie. Jak niejednokrotnie podkreślono $\mathrm{w}$ studiach nad przymusową migracją, działania uchodźców warunkowane są przez podstawową potrzebę poprawy 
warunków swojego życia. Tworzą oni tym samym społeczność samowystarczalną (ang. self-reliant) (Msabah 2019). Jednocześnie, w przypadku sytuacji kryzysowych, niektóre grupy wrażliwe społecznie nie podejmują działań prewencyjnych, aby uchronić się przed konsekwencjami zagrożeń, co często czyni z nich biernych obserwatorów, zamiast agentów zmiany (Lejano, Rahman, Kabir 2020). Za sprawą prezentowanego studium pragnę zwrócić uwagę na warunki życia uchodźców w czasie kryzysu zdrowia publicznego. Poprzez odpowiedź na pytanie o sposób, w jaki sprawczość uchodźców manifestowała się podczas sytuacji kryzysowej, można przyjrzeć się kwestii ich adaptacji do warunków zagrożenia na płaszczyźnie organizacyjnej, społecznej i kulturowej.

\section{Podejście teoretyczne}

Większość teorii definiuje pomyślną integrację uchodźców w kategoriach dostępu do możliwości i zasobów, a także poczucia bezpieczeństwa oraz przynależności do nowego środowiska (Ager, Eyber 2002). W badaniach nad możliwą przyszłością uchodźców (Fiddian-Qasmiyeh, Loescher, Long, Sigona, Milner 2014), lokalna integracja została wskazana jako jedno z trzech „trwałych rozwiązań” (ang. durable solutions) - obok repatriacji i przesiedlenia - a także, jak podkreśla Karen Jacobsen, długo traktowano ją jako „zapomniane rozwiązanie” (Jacobsen 2001). Przesiedlenie uchodźców często nie jest możliwe, a ich repatriacja jest naznaczona przeszkodami. W konsekwencji uchodźcy spędzają wiele lat w strefach przygranicznych lub w obozach dla uchodźców. UNHCR określił to zjawisko ,przedłużającym się stanem zawieszenia” (ang. protracted refugee situations) (UNHCR 2004). Chociaż życie uchodźców w tym swoistym limbo nie jest zagrożone, to jednak ich prawa i potrzeby pozostają głęboko zaniedbane. Przede wszystkim jednak nie są oni w stanie uwolnić się od konieczności przyjmowania pomocy z zewnątrz. Taka sytuacja dotyczy coraz większej liczby azylantów i skłania badaczy do pytania o skuteczne sposoby ich wsparcia. 
W tym powyższym kontekście badania czerpią z antropologii i psychologii. Pojęcie „liminalności” brytyjskiego antropologa Victora Turnera oraz „stan wyjątkowy” Giorgio Agambena (ang. state of exception) były niejednokrotnie wykorzystywane do analizy (Ghorashi, de Boer, ten Holder 2018). Nie mniej istotna jest także sprawczość (ang. agency), posiadająca związek nie tylko ze wspomnianą adaptacją, ale także z praktycznym działaniem. Ruth L. Healey w pracy „Asylum-seekers and refugees: a structuration theory analysis of their experiences in the UK", korzystając z teorii strukturacji Anthony'ego Giddensa, wskazuje na wpływ zmiennych strukturalnych i indywidualnych na doświadczenia osób ubiegających się o status uchodźcy (Healey 2006). Z kolei Beatrice Akua-Sakyiwah, w badaniu poświęconemu sytuacji uchodźców w Ghanie, zwraca uwagę na istnienie barier instytucjonalnych w dostępie dzieci uchodźców do edukacji (Akua-Sakyiwah 2020).

Anthony Giddens, autor teorii strukturacji, wprowadza podział na strukturę, którą tworzą reguły i zasoby zorganizowane jako zmienne konstytuujące systemy społeczne, swoiste ,właściwości strukturalne” oraz na system, na który składają się rutynowe, reprodukowane działania społeczne, formujące relacje między zróżnicowanymi aktorami (Giddens 1984; Turner 1986). Jednocześnie rozpatruje relacje między strukturą a sprawczością ${ }^{1} \mathrm{~W}$ ramach ich ciągłych i współzależnych powiązań. Poprzez koncepcję dwoistości struktury (ang. dualism of structure) obrazuje przyczynowo-skutkową relację między sprawczością a jej wynikiem; struktura wyznacza w tym kontekście zarówno początek, jak i konsekwencje działania. Oznacza to, że istnienie struktury jest warunkowane i podtrzymywane poprzez ciągle reprodukowane interakcje społeczne. Struktura jako zinternalizowany „mentalnie” porządek społeczny - manifestuje się w codziennych ludzkich działaniach warunkowanych przez przepisy prawa, organizację instytucjonalną (tzw. ,zewnętrzne ograniczenia”) (Sewell 1992; Sibeon 2004). Tworzy ona ograniczenia, restrykcje oraz możliwości dla sprawczego działania podmiotu. Jest to zagadnienie dalej rozwijane

${ }^{1}$ A. Giddens stosuje na przemian pojęcie sprawczości (ang. agency) i działania (ang. action) podkreślając, że mają one charakter kontekstowy i powiązany z konkretnym systemem społecznym (Little 2012). 
w ramach konceptu „dialektyki kontroli” (Giddens 1984), oznaczające działanie generowane przez struktury, które jednocześnie nie jest przez nie determinowane. Warto dodać, że Giddens nie sprowadza sprawczości i struktury do ich podstawowej dychotomii, lecz postrzega je jako dwie strony tej samej monety. Skupia swoją uwagę na tzw. ,praktykach społecznych", podkreślając, że podstawowym problemem badań nauk społecznych nie jest doświadczenie indywidualnego aktora, ale praktyki społeczne uporządkowane „w przestrzeni i czasie” (Giddens 1984). Zwraca uwagę, że żaden system kontroli nie może być doskonały, ponieważ podmioty podporządkowane działaniu władzy zawsze cechują się własną kategorią sprawczości (ang. agency) i refleksyjności, czyli zdolności podmiotu do świadomej zmiany (Giddens 1991a; Sweetman 2003). Podmioty mogą zatem zawsze znaleźć sposoby na manifestacje swojego oporu wobec represyjnej struktury (Ortner 2006). Z tych względów to właśnie teoretyczne podejście w analizie przeżyć uchodźców w kontekście relacji między strukturą a sprawczością pomaga zrozumieć charakter ich doświadczeń, bowiem, jak zostanie to omówione w dalszej części artykułu, to właśnie zasady, normy, przepisy prawa, dostosowania instytucjonalne funkcjonujące w ramach ogólnych uwarunkowań strukturalnych określają ich codzienne wybory i aktywność.

\section{Metodologia}

Pandemia COVID-19 wymusiła zastosowanie metod jakościowych, głównie obserwacji uczestniczącej, przeprowadzonej w sierpniu 2019 roku, w środowisku Nakivale Researchers Network (dalej NRN), organizacji pozarządowej założonej z inicjatywy mieszkańców obozu z Nakivale. Do jej głównych zadań należy prowadzenie prac badawczych dotyczących sytuacji uchodźców, współpraca z przedstawicielami środowiska naukowego oraz kontrola etycznej strony eksploracji podejmowanych przez zagranicznych naukowców zajmujących się uchodźcami w tej miejscowości. Reprezentanci NRN zwrócili uwagę, że od 2019 roku uchodźcy, pozostający we wspomnianym wyżej stanie zawieszenia, zmagają się 
wciąż z licznymi problemami egzystencjalnymi, które pogłębia pandemia. $Z$ wielu rozmów wynikało, że sytuacja ta posiada istotny wpływ na poczucie ich sprawstwa. W eksploracji posługiwałem się także zdalnym wywiadem terenowym (ang. remote fieldwork), konceptem „współobecności” (ang. co-presence) (Beaulieu 2010; Pink, Horst, Postill, Hjorth, Lewis, Tacchi 2015) oraz „technologiami życia” (ang. technologies of life) (Cruz, Harindranath 2020). Celem współobecności jest osiągnięcie zrozumienia poprzez interakcję i - często - osobiste relacje. Można je zatem kultywować na wiele sposobów, nieograniczonych do fizycznego przebywania w miejscu realizacji badań (Beaulieu 2010; Goffman 1957, 1971). Poprzez nawiązanie przeze mnie relacji z przedstawicielami NRN możliwe było kontynuowanie interakcji nawet po opuszczeniu terenu. Jednocześnie, decydując się na utrzymanie intensywnego kontaktu zdalnego, zastosowałem tzw. technologie życia, przez które Edgar Gómez Cruz i Ramaswami Harindranath rozumieją technologię (lub grupę technologii), która podtrzymuje, a zarazem kształtuje całe spektrum codziennych aktywności osobistych, zawodowych, duchowych i politycznych. Wśród owych ,technologii” Cruz i Harindranath wyróżniają m.in. komunikator What's App, który ze względu na swoją popularność w Afryce stał się ważnym narzędziem wykorzystywanym w zdalnych badaniach terenowych (Cruz, Harindranath 2020).

\section{Przed pandemią. Życie w ciągłym stanie zawieszenia}

Pierwszą zmienną, a zarazem polem interakcji, którą warto przedstawić w kontekście analizy sprawczości uchodźców w czasie pandemii COVID-19 jest szkolnictwo, które - według UNHCR - chroni i upodmiotawia dzieci oraz młodzież z rodzin uchodźczych, zapewniając umiejętności potrzebne do prowadzenia niezależnego życia (UNHCR 2021). Teoria strukturacji Giddensa może pozwolić w tym przypadku na kontekstowe zrozumienie edukacji, jaką otrzymują dzieci uchodźców w Nakivale, a także pomóc $\mathrm{w}$ analizie potrzeb, których zaspokojenie może wzmocnić sprawczość podmiotu. 
W Nakivale jest kilka szkół podstawowych, zarówno publicznych, jak i prywatnych. Miejsce w szkołach publicznych jest bezpłatne, ale poziom nauczania jest niski, a wszystkie lekcje prowadzone są w języku angielskim. Inaczej prezentuje się sytuacja w szkołach prywatnych, gdzie dziecko może liczyć na naukę języka angielskiego (oficjalnego języka w Ugandzie), a nauczyciele często posiadają umiejętność porozumiewania się w językach uchodźców (francuskim lub suahili). Jak wskazywali uchodźcy w 2019 roku, administracja obozu nie robi wystarczająco dużo, aby poprawić ich jakość życia, zwłaszcza w kontekście dostępu do edukacji. W studiach nad migracją wskazuje się na powszechną praktykę podejmowaną przez państwo przyjmujące, która polega na ograniczaniu działalności szkół i lokalnych firm w obozach, w celu zniechęcenia azylantów do stałego osiedlania się w nich. Badacze zjawiska wskazują również, że członkowie organizacji wspierających uchodźców wykazują frustrację w rozwiązywaniu ich problemów, a prowadzone przez nich działania przyjmują różne, nie zawsze spójne i przejrzyste formy (Griffiths 2001). Potwierdza to założenia teorii Giddensa, który zwrócił uwagę, że interakcje między strukturą społeczną a sprawczością podmiotu prowadzą często do komplikacji, chociaż paradoksalnie tylko aktywność aktorów społecznych (ang. human agents) może zapewnić ciągłość (tj. przetrwanie) struktury. W omawianym przypadku rezultat tej interakcji jest jednak niekorzystny dla uchodźców. Poprzez ograniczania dostępu do edukacji - co może stanowić próbę zachowania status quo w sposobie przekazywania wiedzy i organizacji placówek edukacyjnych w Ugandzie szanse dzieci uchodźców na skuteczną integrację ze społeczeństwem przyjmującym są nikłe. Najmłodsi azylanci są ofiarami utrwalania szkodliwych dysproporcji rozwojowych. Co więcej, rolniczy charakter życia w Afryce Środkowej, a także ograniczona mobilność spowodowana różnorodnością językową i etniczną, sprawiają, że teren osady w Nakivale staje się de facto ich jedyną możliwą przestrzenią życiową. Świadczą o tym dane: 6\% uchodźców w Ugandzie mieszka w stolicy kraju Kampali - jednak ich większość, czyli 94\%, mieszka na stałe w jednym z 13 obozów rozmieszczonych na terytorium kraju (WFP 2021). W trakcie obserwacji uchodźcy niechętnie komentowali perspektywy życia 
w Nakivale, wskazując, że w osadzie panują złe warunki bytowe. Warto zauważyć, że najbliższy ośrodek szkoleniowy, który finansowany jest m.in. przez UNHCR, znajduje się godzinę drogi od obozu (Silva 2019). Wszystko to negatywnie rzutuje na rozwój sprawczości uchodźców. Beatrice Akua-Sakyiwah w pracy poświęconej działalności azylantów w warunkach obozu w Ghanie zwraca uwagę na dyrektorów placówek edukacyjnych, którzy przyjmują rolę „oficerów reform” (ang. reforming officers), pilnujących przestrzegania zasad i zapewniających ciągłość istnienia struktury. Tym samym w instytucji szkoły dostrzegamy idee Giddensa dotyczącą struktury, która jest reprodukowana i podtrzymywana poprzez określone interakcje społeczne zachodzące w zdefiniowanych ramach regulacyjnych (Akua-Sakyiwah 2020) - w tym przypadku są nimi zarówno przepisy prawa krajowego dotyczące funkcjonowania szkół, jak i modele nauczania oraz ograniczenia, które są nieodłączną częścią doświadczeń uchodźców (w tym: niezdolność do płacenia czesnego, bariery językowe, niewystarczająca liczba placówek edukacyjnych). Wszystko to rzutuje negatywnie na zdolność podmiotu do uzyskania nawet podstawowego wykształcenia.

Drugą zmienną, która determinuje zaistnienie sprawczości uchodźców, jest odczuwana przez nich szansa powodzenia wszelkiego rodzaju inicjatyw (indywidualnych lub grupowych). Giddens zwraca uwagę na rolę aktora społecznego w transformacji reguł rządzących strukturą, która w przypadku obozu w Nakivale manifestuje się poprzez oddolne projekty podejmowane przez azylantów i mające na celu poprawę warunków ich życia. Często napotykają oni jednak przeszkody. Wśród zmiennych osłabiających potencjał uchodźców do prowadzenia oddolnych działań wyróżnia się często aspekt przywództwa w społecznościach lokalnych. Jak podkreślają Alastair Ager i Alison Strang, kwestia relacji społecznych wśród społeczności imigranckiej wpływa na jej zdolność do integracji, ma konsekwencje dla poczucia sprawczości uchodźców i często prowadzi do ich bierności (Ager, Strang 2008). Niemniej istotne jest wsparcie organizacyjne ze strony podmiotów i instytucji organizujących pomoc dla uchodźców lub regulujących ich status formalnoprawny. Niejednokrotnie zwracano moją uwagę na fakt nieotrzymywania przez 
uchodźców odpowiedzi na ich zapytania, ignorowanie ich inicjatyw i pomysłów, które miałyby przyczynić się do poprawy jakości życia w osadzie w Nakivale. W takich sytuacjach często obserwowałem poczucie bezsilności i braku perspektyw wśród uczestników badania, co w konsekwencji prowadziło do zaniechania działań podejmowanych przez nich na rzecz swoich społeczności.

Według Michela Foucault władza nie jest tylko czymś zewnętrznym wobec podmiotu, ale okazuje się integralnym składnikiem mentalnych, dyskursywnych i behawioralnych wzorców jego sprawczości (Foucault 1980). Relacje władzy okazują się zatem szczególnym polem, w którym rozgrywa się status mieszkańców obozu w Nakivale. Zwykle pojawia się tu kwestia asymetrii - uchodźcy mogą po prostu „mniej” niż inne grupy, od których zależy ich funkcjonowanie. Jest to zatem trzecia zmienna, decydująca o zaistnieniu i umacnianiu sprawczości tych ludzi. Jako taka wyraża się przez podejmowanie przez nich oddolnych inicjatyw w kontekście ich „stanu zawieszenia” oraz jednoczesnego ich uzależnienia od pomocy oferowanej niemal stale przez organizacje humanitarne lub władze państwa przyjmującego. W praktyce uchodźcy odczuwają znaczną nierównowagę: mają poczucie ograniczenia ich sprawczości, wywołane (co widać dobrze z pozycji obserwatora) wpływem społecznych sił zewnętrznych i wewnętrznych.

Uzupełniając perspektywę Foucaulta o odniesienia do teorii Giddensa, warto podkreślić, że sprawczość uchodźców jest warunkowana przez określone zasady, normy i przepisy prawa państwa przyjmującego. To one tworzą ramy działania, w których rozgrywa się życie uchodźców. Wiąże się to ze wspomnianą koncepcją dwoistości struktury. Kierownictwo obozu, instytucje międzynarodowe i pozarządowe organizują i kontrolują sprawczość podmiotu. Uchodźcy, w tym przypadku, rozpatrują swoją egzystencję poprzez określoną relację społeczną, pomiędzy sobą „MY - uchodźcy” a „zewnętrznymi ograniczeniami” wpływającymi na ich działanie. Tu ujawniały się zatem sposoby postrzegania przez nich organizacji, z którymi mają kontakt. Wśród nich szczególnie miejsce zajmuje Urząd Premiera Ugandy, który administruje terenem osady w Nakivale. Podczas obserwacji uczestniczącej przeprowadzonej 
w 2019 roku i później zaobserwowałem, że azylanci obawiają się Urzędu Premiera, jednak zwracają się do niego w różnych sprawach formalnoprawnych. Relację tę można scharakteryzować, wykorzystując terminy kontroli i uzależnienia (Harrell-Bond 1986). Jak wskazują Evan EastonCalabria i Maurice Herson (Easton-Calabria, Herson 2020) nie ma nic złego w poleganiu na instytucjach lub we wsparciu z ich strony, jednak, jak słusznie wspominają, relacja ta powinna opierać się na podejściu konstruktywnym. Tymczasem uchodźcy, kontaktując się z Urzędem Premiera, niechętnie opowiadają o historiach swojego życia, obawiając się, że mogą one negatywnie wpłynąć na ich status. Inaczej relacja wygląda w przypadku UNHCR, do którego przedstawicieli uchodźcy często się zwracają, co stanowi duże wyzwanie dla obu stron. Uchodźcy nie boją się również szukać pomocy u innych organizacji, jednak odczuwają niski poziom zadowolenia ze świadczonych przez nie usług. Oczywiście ich oczekiwania mogą być niewspółmierne do zasobów i kompetencji organizacji, co należy uwzględnić w badaniach nad tym zjawiskiem.

Czwartą, poddaną obserwacji zmienną, istotną z punktu widzenia sprawczości uchodźców oraz w kontekście trwającej pandemii COVID-19, jest opieka zdrowotna. Jest to obszar najgorzej funkcjonujący w obozie Nakivale. W artykule napisanym przez uchodźcę z Demokratycznej Republiki Konga i opublikowanym na blogu „Życie w Nakivale” czytamy: „Zachorowanie przez uchodźcę jest jak bycie skazanym na śmierć. Uchodźcy zawsze chorują i nie otrzymują wystarczającej opieki medycznej w szpitalu. To tak, jakby twój status uchodźcy czynił cię niewidzialnym” (Joël 2020a). Termin „niewidzialność” można odczytać, za Francisem Fukuyamą (2018), jako utratę godności². W Nakivale, gdzie dostęp azylantów do podstawowej opieki zdrowotnej jest bardzo utrudniony (pomimo obecności szpitala), uchodźcy zmagają się z traumą, chorobami

2 Pojęcie niewidzialności można odnieść do konceptu „niewidzialnego człowieka” przedstawionego w powieści Ralpha Ellisona pod tym samym tytułem (Ellison 1972). Francis Fukuyama, aby zrozumieć przesłanie Ellisona, wskazuje w swoje książce Tożsamości. Współczesna polityka tożsamościowa i walka o uznanie na uniwersalną potrzebę człowieka związaną z poczuciem godności. Jak podkreśla, prawdziwą zniewagą rasizmu na Północy było to, że Afroamerykanie niekoniecznie byli źle traktowani, ale zwyczajnie niepostrzegani jako bliźni (Fukuyama 2018). 
oraz silnym poczuciem niższości. Niemniej jednak jest to stan, z którym potrafią na swój sposób walczyć. Giddens niejednokrotnie podkreśla, że podmioty są w stanie do pewnego stopnia krytycznie ocenić swoją sytuację i rozwinąć zdolność do oporu (Giddens 1984; Ortner 2006). Nie twierdzi jednocześnie, że jednostki są zawsze w pełni tego świadome, natomiast zaznacza, że pomimo ograniczeń w ich sprawczości, mogą one „postąpić inaczej” (Giddens 1984). Zdolność do krytycznej oceny swojego położenia okaże się kluczowa w ograniczaniu konsekwencji pandemii COVID-19.

\section{Życie podczas pandemii COVID-19}

Chociaż w pierwszych miesiącach pandemii Uganda była stosunkowo niedoświadczona śmiertelnością i wysokimi wskaźnikami infekcji, to jej władze już 18 marca 2020 roku zdecydowały się na restrykcje. Zakazano więc korzystania ze środków transportu publicznego, udziału w zgromadzeniach publicznych, w tym w ceremoniach religijnych, a także handlu w sklepach niespożywczych. Ten ostatni zakaz egzekwowano przy pomocy służb bezpieczeństwa. 30 marca prezydent Ugandy wprowadził także godzinę policyjną od 19:00 do 6:30 (Olum, Bongomin 2020). W tym kontekście uchodźcy stali się w dużej mierze zależni od bieżącej pomocy humanitarnej ${ }^{3}$. Jednocześnie organizacje udzielające wsparcia uchodźcom same podlegały ograniczeniom zewnętrznym, zmagając się wielokrotnie np. z opóźnieniami w dostawach żywności. Możliwości pomocy były zatem zredukowane.

W czasie pandemii COVID-19 do takiej sytuacji doszło, kiedy Światowy Program Żywnościowy (WFP) zmniejszył racje żywnościowe dystrybuowane w obozach do $70 \%$ od kwietnia 2020 roku, a następnie do $60 \%$ od lutego 2021 roku. Obecnie trwają przygotowania do wdrożenia

3 Jednocześnie niewidzialność jest przejawem stanu zawieszenia, zahamowania naturalnej sprawczości - w przypadku uchodźców - poprzez uzależnienie uchodźców od permanentnej pomocy humanitarnej. Szerszą perspektywę analizowanego fenomenu można znaleźć w książce Karawana kryzysu. Za kulisami przemysłu pomocy humanitarnej autorstwa Lindy Polman (2011). 
hierarchizacji zasobów dostępnych dla pomocy żywnościowej. W ramach tymczasowego rozwiązania, od października do listopada 2021 roku, wdrożone zostało podejście polegające na ustalaniu priorytetów geograficznych, na podstawie których 13 obozów dla uchodźców w Ugandzie podzielono na grupy w oparciu o ogólne poziomy podatności na zagrożenia. Nakivale otrzymało obniżoną do $40 \%$ rację żywnościową (Schlein 2020; WFP 2021). Oznacza to, że przed pandemią część uchodźców otrzymywała co miesiąc $22000 \mathrm{UGX}^{4}$ (25,71 PLN), natomiast nowo przybyli: $12 \mathrm{~kg}$ kukurydzy, $3 \mathrm{~kg}$ fasoli, olej i dwie kostki mydła. Od momentu wprowadzenia pierwszych obostrzeń wsparcie dla uchodźców (nie uwzględniając nowo przybyłych) zostało zmniejszone do 19000 UGX (22,21 PLN). Obecnie wynosi 13000 UGX (15,19 PLN).

Ponadto racje żywnościowe nigdy nie wystarczały na przeżycie w obozie. Większość azylantów utrzymywała się zatem z drobnej działalności $\mathrm{w}$ takich branżach jak: transport (z ograniczeniami w czasie pandemii), hodowla ${ }^{5}$, handel, krawiectwo, fryzjerstwo, rękodzieło. Obóz dla uchodźców obejmuje duży obszar i nie wszystkie punkty dystrybucji żywności znajdowały się w odległości możliwej do pokonania piechotą. Znalezienie pożywienia wymagało więc wysiłku i często kilkugodzinnej podróży. Było to szczególnie trudne dla osób chorych i starszych. W artykule autorstwa uchodźcy z Nakivale opublikowanym w polskim czasopiśmie „Wszystko Co Najważniejsze” czytamy:

Pewna osoba mówiła mi, że otrzymuje jedzenie, ale nie wystarcza ono dla niej i jej rodziny. Nie mają węgla ani drewna, aby coś ugotować. Jedzą więc surowe produkty. Cierpią, chorują, nie mogą liczyć na leczenie. Do szpitala trzeba dotrzeć wczesnym rankiem, ale pacjent zostanie przyjęty dopiero wieczorem - wyjdzie wówczas z lekami, które nie mają zastosowania w leczeniu jego choroby (Joël 2020c).

${ }^{4}$ UGX, czyli szyling ugandyjski to w przeliczeniu 0,001169 PLN - według kursu średniego podanego przez Narodowy Bank Polski na dzień 26.11.2021 r.

${ }^{5}$ Niektórzy uchodźcy mają uprawy daleko od miejsca zamieszkania, ale z powodu zakazu korzystania ze środków transportu nie mogli do nich dotrzeć. 
Oprócz tego, po wprowadzeniu godziny policyjnej w Nakivale, nasiliły się problemy społeczne: przemoc ze strony służby obronnej wobec osób naruszających obowiązujące przepisy, wzrost liczby małżeństw zawieranych przez osoby nieletnie, nadużywanie alkoholu, nieplanowane ciąże i uzależnienie od narkotyków. Munir Safieldin, przedstawiciel UNICEF w Ugandzie, poinformował, że w okresie od marca 2020 roku do czerwca 2021 roku nastąpił wzrost wskaźnika ciąż wśród dziewcząt w wieku 10-24 lat o ponad 22,5\%. Tylko w czerwcu 2020 roku poinformowano o ponad 600 kolejnych przypadkach. Zgłaszane sprawy obejmowały wykorzystywanie seksualne, a nawet jeden przypadek morderstwa. 2 na 10 dzieci spożywało mniej niż jeden posiłek dziennie z uwagi na brak dostępu do programów żywienia szkolnego (Safieldin 2021). Takie informacje wskazują na rosnącą potrzebę interwencji. Giddens zauważa, że wszystkie interakcje społeczne, do jakich dochodzi w ramach struktury, są uzależnione od określonych zasad i zasobów przypisanych do - podtrzymujących jej istnienie - podmiotów. Przemoc i rozwój patologii społecznych, które mogły wystąpić w czasie pandemii COVID-19, obrazują jednak dysproporcje w rozdziale zasobów lub nawet przykłady manipulacji strukturą i jej wykorzystywania na rzecz zaspokajania własnych interesów.

Szczególnie wrażliwą sferą dotkniętą pandemią okazała się edukacja. Uganda znalazła się wśród 20 krajów o największej liczbie dni pełnego zamknięcia szkół od początku pandemii. UNESCO podało, że dziecko w Ugandzie opuściło 149 dni szkolnych w okresie od marca 2020 roku do lutego 2021 roku (UNESCO 2021). W związku z zawieszeniem nauki w szkołach Ministerstwo Oświaty przekazało do domów uczniów materiały edukacyjne. Chociaż nauczyciele w obozie dla uchodźców w Nakivale starali się monitorować naukę uczniów, odwiedzając ich w domu, często nie spotykali ich na miejscu. Niejednokrotnie uczniowie nie wywiązywali się z obowiązków szkolnych z powodu prac domowych. Podczas wywiadu przeprowadzonego przez badaczy z NRN jedna z matek powiedziała, że dzieci są zmuszane do wykonywania prac w domu, aby uchronić je przed szkodliwymi zachowaniami społecznymi, do których dochodzi, gdy pozbawione są nadzoru. 
Nauczyciele odgrywają szczególną rolę w strukturze społecznej. Ich zadanie nie ogranicza się jedynie do współtworzenia systemu poprzez udział w codziennych interakcjach, ale są oni również nośnikami (za sprawą procesu nauczania) praw, reguł, zasad i norm, które umacniają istnienie struktury. Ograniczenie edukacji w obozie w Nakivale przez pandemię COVID-19, oprócz destrukcyjnych konsekwencji rozwojowych dla dzieci uchodźców, niesie także zagrożenie dotyczące przerwania procesu nauczania, w którym aktorzy społeczni uczą się rozpoznawać reguły oraz role, których reprodukcja podtrzymuje trwanie struktury.

\section{Sprawczość i zmiana w czasie pandemii}

Podkreślając rolę sprawczości podmiotu, Giddens przywołuje koncept „agenta celu” (ang. purposive agents), przez którego rozumie jednostkę zarówno świadomą rezultatów swoich działań, jak i potrafiącą je uargumentować (Ma 2010). Giddensowi nie chodzi jednak o serię niepowiązanych działań podejmowanych ad hoc, ale raczej ciągły sposób postępowania (ang. flow of conduct) (Giddens 1984), który umacnia istnienie struktury poprzez podtrzymywanie dynamiki interakcji (w ramach reprodukowanych reguł) między konstytuującymi ją aktorami, działającymi w ramach określonych ram regulacyjnych. W tym kontekście szczególnego znaczenia nabierają projekty realizowane w czasie pandemii COVID-19 przez organizacje pozarządowe założone przez uchodźców. Do ich przykładów należy przygotowanie materiałów informacyjnych na temat zagrożeń związanych z wirusem SARS-CoV-2. Dieudonné Kikalage Joël ${ }^{6}$, uchodźca, nauczyciel i założyciel placówki edukacyjnej Built to Become Competent, przy współpracy z NRN sformułował arkusz informacyjny na temat COVID-19 w trzech językach: suahili, francuskim i kinyarwanda. Ulotki zostały rozdane nauczycielom, uczniom i rozwieszone w strategicznych miejscach obozu, w tym w szkołach.

${ }^{6}$ Dieudonné Kikalage Joël wyraził zgodę na podanie jego pełnego imienia i nazwiska oraz zawodu w tym artykule. 


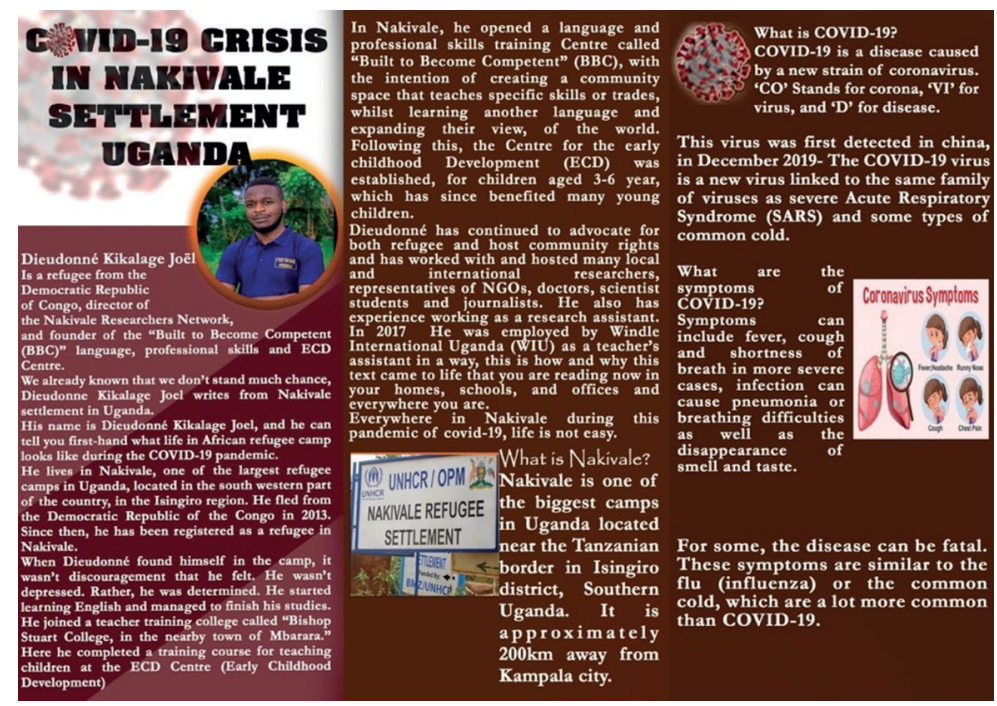

Fot. 1. Pierwsza strona materiału informacyjnego poświęconego wirusowi SARS-CoV-2 oraz skutecznym środkom ochrony przed zakażeniem (Źródło: archiwum autora).

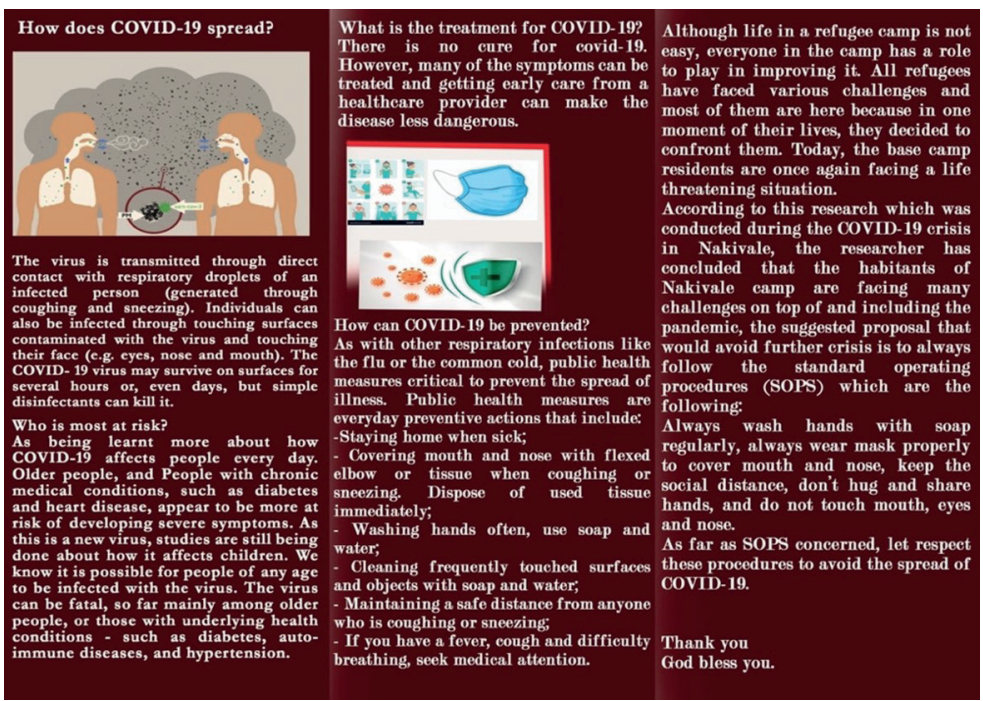

Fot. 2. Druga strona materiału informacyjnego poświęconego wirusowi SARS-CoV-2 oraz skutecznym środkom ochrony przed zakażeniem (Źródło: archiwum autora). 
Giddens niejednokrotnie zaznacza, że sprawczy podmiot (ang. agent) ma możliwość oddziaływania w celu osiągnięcia zmiany reguł rządzących strukturą poprzez konkretne działanie (sprawczość). W przypadku, kiedy owa zdolność zanika lub jest ograniczana przez strukturę, konsekwencje zachodzą przede wszystkim w samoświadomości i samopoczuciu podmiotu, najczęściej w postaci rosnącego poczucia jego rezygnacji lub bezsilności. Przykład materiałów informacyjnych opracowanych przez NRN i organizację Built to Become Competent ilustruje siłę indywidulanej sprawczości w transformacji reguł rządzących strukturą. To oddolna działalność zainicjowana i wspierana przez nauczycieli przyczyniła się do sformułowania nowych reguł interakcji w ramach struktury, uwzględniając uwarunkowania zewnętrzne związane z zagrożeniem zdrowotnym. Motywacja podmiotów do podjęcia takich działań wynikała $\mathrm{z}$ racjonalnej potrzeby upowszechnienia dobrych praktyk, które mogą łagodzić konsekwencje pandemii COVID-19 i zapewnić uchodźcom poczucie bezpieczeństwa (według Giddensa jest to bezpieczeństwo „ontologiczne”) (Giddens 1991b: 35-42). Mimo że inicjatywa ta nie uzyskała wsparcia ze strony instytucji międzynarodowych ani administracji, to strony te aprobowały konieczność jej realizacji.

Kolejnymi przykładami oddolnych inicjatyw podczas pandemii COVID-19 są projekty organizowane przez Young Africans Refugees Entrepreneurs Network (YAREN), organizację założoną przez grupę uchodźców mieszkających w Nakivale od 2015 roku. Razem z fundacją Yourghas z siedzibą w Polsce zorganizowali 3 października 2020 roku społeczną inicjatywę na temat higieny intymnej i wyzwań zdrowotnych związanych z pandemią wśród uchodźców w osadzie w Nakivele.

Ważne jest, aby zauważyć, że życie uchodźców, czy to w obozach, czy w miastach, jest pełne cierpienia. Dlatego konieczne jest zwiększenie świadomości społecznej na temat trudnej sytuacji uchodźców w celu opracowania strategii, które pomogą zmienić źródła utrzymania uchodźców. To jest powód, aby uzasadnić wagę tej interwencji, ponieważ w ciągu ostatnich 6 miesięcy sytuacja wydaje się pogarszać. Utrata kapitału biznesowego, brak pracy i ograniczone możliwości mogą prowadzić do wielu niepożądanych ciąż 
wśród nastolatków, którym trudno uzyskać wysokiej jakości zestawy menstruacyjne zapobiegające różnym chorobom (Tekst pojawił się w poście na portalu społecznościowym Facebook „Organizacja YAREN" 6.10.2020 roku).

Szkolenie z zakresu higieny intymnej i bezpieczeństwa zdrowotnego dla kobiet w Nakivale prowadziła również organizacja Opportunigee. W tym wieloetnicznym środowisku uchodźczym, gdzie edukacja seksualna wciąż jest tematem tabu, wraz z obserwacją rosnącej liczby młodych dziewcząt wchodzących w pierwszą, nieplanowaną ciążę, ten rodzaj zajęć okazuje się konieczny. Innym projektem przeprowadzonym przez organizację Yaren było szkolenie dla liderów grup w obozie na temat stosowania filtrów do wody. Projekt stanowił część inicjatywy Sawyer Water Filter zorganizowanej przez SUKHI 222. Yaren przekazał również uchodźcom szczególnie narażonym na zakażenie osłony na twarz chroniące przed wirusem SARS-CoV-2. Warto tu także wskazać inicjatywę Opportunigee, która wspólnie z organizacją Alight opracowała bezdotykowy system mycia rąk. Specjalne stacje i zbiorniki na wodę zostały rozmieszczone w różnych miejscach obozu w odpowiedzi na zagrożenie związane z kryzysem zdrowia publicznego.

Ponadto uchodźcy w sytuacji „zawieszenia”, pogłębionej dodatkowo przez warunki pandemii, prowadzą akcje wydawnicze na temat ich aktualnej sytuacji. Informowanie nie omija także naszego kraju - w polskim czasopiśmie „Wszystko Co Najważniejsze” ukazały się bowiem dwa artykuły w językach polskim, angielskim i francuskim (Joël 2020b, 2020c). W pierwszym, opublikowanym w maju 2020 roku pt. „Żyjemy, jeszcze żyjemy", autor opisuje doświadczenie uchodźców w Nakivale w kontekście wprowadzonych restrykcji, podkreślając, że to nie pandemia jest największym problemem azylantów, ale m.in. brak czystej wody. Drugi artykuł został opublikowany we wrześniu 2020 roku i dotyczył wpływu pandemii COVID-19 na edukację dzieci uchodźców, zwłaszcza pomysłu zawieszenia działalności szkół i jego konsekwencji. 


\section{Wnioski}

Teoria strukturacji Giddensa zastosowana do analiz wyników badań pozwoliła rzucić światło na dynamikę interakcji międzyludzkich w obozie dla uchodźców w Nakivale oraz na jej powiązanie ze strukturami społecznymi (normami prawnymi, zasobami, kompetencjami, zasadami i zwyczajami regulującymi sprawczość podmiotu). Świat uchodźców z Nakivale odsłania sposób, w jaki regulują oni zasady swojego życia, zwłaszcza w sytuacji kryzysowej jaką jest pandemia COVID-19. Tu uwidoczniła się z kolei rola ludzkiego agenta, z jednej strony podtrzymującego istnienie struktury, a z drugiej zagrożonego jej zmianą - jak w przypadku ryzyka płynącego z przerwania utrwalonych praktyk społecznych.

Działaniom mieszkańcom Nakivale na rzecz poprawy warunków życia przewodziły organizacje pozarządowe. Tymczasem istotny dla realnej poprawy dobrostanu tych ludzi okazuje się proces nabywania przez nich poczucia sprawstwa, które w konsekwencji umożliwia samodzielność (Zimmerman 1995). Ma to istotne znaczenie, bowiem jak ilustrują przykłady działań uchodźców w czasie pandemii COVID-19, choć z pewnością udało im się zachować poczucie sprawczości, ograniczenia nakładane na nich przez strukturę, a także zagrożenia związane z przerwaniem praktyk społecznych, przede wszystkim w zakresie edukacji, mogą przyczynić się do fiaska polityki integracyjnej.

\section{Podziękowania}

Artykuł został napisany we współpracy z Nakivale Researchers Network i z pomocą asystenta naukowego Dieudonné Kikalage Joëla, któremu dziękuję także za udzielenie mi informacji i okazaną pomoc. 


\section{Bibliografia}

Ager, A., Eyber, C. (2002). Indicators of Integration: A Review of Potential Indicators'. Report to the Home Office Immigration Research and Statistics Service.

Ager, A., Strang, A. (2008). Understanding Integration: A Conceptual Framework. Journal of Refugee Studies, 21 (2). doi: 10.1093/jrs/fen016 Ahimbisibwe, F. (2019). Uganda and the refugee problem: challenges and opportunities. African Journal of Political Science and International Relations, 13 (5). doi: 10.5897/AJPSIR2018.1101

Akua-Sakyiwah, B. (2020). Intersecting social structures and human actors: Ganfoso refugees' settling experiences and impact on children's education. Comparative Migration Studies, 8 (1). doi: 10.1186/s40878020-00202-4

Beaulieu, A. (2010). Research Note: From co-location to co-presence: Shifts in the use of ethnography for the study of knowledge. Social Studies of Science, 40 (3), 453-470. doi: 10.1177/0306312709359219

Cruz, E.G., Harindranath, R. (2020). WhatsApp as "technology of life": Reframing research agendas. First Monday. doi: 10.5210/fm. v25i12.10405

Easton-Calabria, E., Herson, M. (2020). In praise of dependencies: dispersed dependencies and displacement. Disasters, 44 (1). doi: 10.1111/ disa. 12366

Ellison, R. (1972). Invisible Man. New York: A Vintage Book.

Fiddian-Qasmiyeh, E., Loescher, G., Long, K., Sigona, N., Milner, J. (2014). Protracted Refugee Situations. In: The Oxford Handbook of Refugee and Forced Migration Studies. Oxford: Oxford University Press. doi: 10.1093/oxfordhb/9780199652433.013.0038

Foucault, M. (1980). Power/Knowledge. New York: Pantheon Books.

Fukuyama, F. (2018). Identity: The Demand for Dignity and the Politics of Resentment. New York: Farrar, Straus and Giroux.

Ghorashi, H., de Boer, M., ten Holder, F. (2018). Unexpected agency on the threshold: Asylum seekers narrating from an asylum seeker centre. Current Sociology, 66 (3), 373-391. doi: 10.1177/0011392117703766 
Giddens, A. (1984). The Constitution of Society. Outline of the Theory of Structuration. Cambridge: Polity Press.

Giddens, A. (1991a). Modernity and Self-Identity: Self and Society in the Late Modern Age. Cambridge: Polity Press.

Giddens, A. (1991b). The self: Ontological security and the existential anxiety. In: A. Giddens, Modernity and selfidentity: Self and society in the late modern age. California: Stanford University Press.

Goffman, E. (1957). Alienation from Interaction. Human Relations, 10 (1), 47-60. doi: 10.1177/001872675701000103

Goffman, E. (1971). The Territories of the Self. In: Relations in Public. Microstudies of the Public Order (p. 28-61). London: Allen Lane Penguin Press.

Griffiths, P. (2001). Counselling asylum seekers and refugees: a study of Kurds in early and later stages of exile. European Journal of Psychotherapy \& Counselling, 4 (2). doi: 10.1080/13642530110073275

Harrell-Bond, B.E. (1986). Imposing aid: emergency assistance to refugees. Oxford: Oxford University Press.

Healey, R.L. (2006). Asylum-seekers and refugees: a structuration theory analysis of their experiences in the UK. Population, Space and Place, 12 (4). doi: $10.1002 / p s p .412$

Jacobsen, K. (2001). The forgotten solution: local integration for refugees in developing countries. Working Paper No. 45. Pozyskano z https:// www.unhcr.org/research/working/3b7d24059/forgotten-solutionlocal-integration-refugees-developing-countries-karen.html.

Joël, D. (2020a). At the hospital in the refugee camp. 25.08.2021. Pozyskano z https://lifeinnakivale.wordpress.com/.

Joël, D. (2020b). Pandemia zmarnuje nasze wysiłki w walce $\mathrm{z}$ analfabetyzmem. Wszystko Co Najważniejsze. Pozyskano z https://wszystkoconajwazniejsze.pl/dieudonne-kikalage-joel-pandemia-zmarnuje-caly-postep-we-walce-z-analfabetyzmem-ostatnich-lat/.

Joël, D. (2020c). We are alive, still alive. Wszystko Co Najważniejsze. Pozyskano z https://wszystkoconajwazniejsze.pl/dieudonne-kikalagejoel-we-are-alive-still-alive/. 
Lejano, R.P., Rahman, M.S., Kabir, L. (2020). Risk Communication for Empowerment: Interventions in a Rohingya Refugee Settlement. Risk Analysis, 40 (11). doi: 10.1111/risa.13541

Little, D. (2012). Giddens on Agents and Structures. Understanding Society. Pozyskano z https://undsoc.org/2012/06/09/giddens-onagents-and-structures/.

Ma, L. (2010). Theory and Education: A Case of Structuration Theory. Indiana University - Bloomington. Pozyskano z http://hdl.handle. net/2142/14934.

Msabah, B.A. (2019). Refugee migrants as agents of change: Strategies for improved livelihoods and self-reliance. Verbum et Ecclesia, 40 (1). doi: $10.4102 /$ ve.v40i1.1851

Olum, R., Bongomin, F. (2020). Uganda's first 100 COVID-19 cases: Trends and lessons. International Journal of Infectious Diseases, 96. doi: 10.1016/j.ijid.2020.05.073

Ortner, S.B. (2006). Anthropology and Social Theory. Durham: Duke University Press. doi: 10.1215/9780822388456

Pink, S., Horst, H., Postill, J., Hjorth, L., Lewis, T., Tacchi, J. (2015). Digital Ethnography: Principles and Practice. London: Sage Publications Ltd.

Polman, L. (2011). Karawana kryzysu. Za kulisami przemysłu pomocy humanitarnej. Wołowiec: Wydawnictwo Czarne.

Safieldin, M. (2021). Prioritize re-opening of schools to secure children's well being . Pozyskano z https://www.unicef.org/uganda/press-releases/prioritize-re-opening-schools-secure-childrens-well-being.

Schlein, L. (2020). WFP to Cut Refugee Food Rations in Uganda for Lack of Cash. Voice of America, 25.03.2021. Pozyskano z https://www. voanews.com/africa/wfp-cut-refugee-food-rations-uganda-lack-cash.

Sewell, W.H. (1992). A Theory of Structure: Duality, Agency, and Transformation. American Journal of Sociology, 98 (1), 1-29. doi: $10.1086 / 229967$

Sibeon, R. (2004). Rethinking Social Theory. London: Sage Publications Ltd. doi: 10.4135/9781446216989 
Silva, M. (2019). Nakivale Refugee Settlement and its settlers. Pozyskano z https://marijosilvaphotography.com/Nakivale-Refugee-Settlementand-its-settlers.

Sweetman, P. (2003). Twenty-First Century Dis-Ease? Habitual Reflexivity Or the Reflexive Habitus. The Sociological Review, 51 (4), 528-549. doi: 10.1111/j.1467-954X.2003.00434.x

Turner, J.H. (1986). The Theory of Structuration The Constitution of Society: Outline of the Theory of Structuration. Anthony Giddens. American Journal of Sociology, 91 (4), 969-977. doi: 10.1086/228358

UNESCO. (2021). Global Monitoring of School Closures Caused by COVID-19 Pandemic report. Pozyskano z http://covid19.uis.unesco. org/global-monitoring-school-closures-covid19/.

UNHCR. (2004). "Protracted Refugee Situations". Standing Committee, 30th meeting report (No. EC/54/SC/CRP.14).

UNHCR. (2021). Education. Pozyskano z https://www.unhcr.org/education.html.

WFP. (2021). Uganda: Joint sharing of information with refugees on the prioritisation of WFP's food assistance.

Zimmerman, M.A. (1995). Psychological empowerment: Issues and illustrations. American Journal of Community Psychology, 23 (5). doi: 10.1007/BF02506983 